\title{
Bacterial disease of cultured giant clam Tridacna gigas larvae
}

\author{
D. C. Sutton, R. Garrick \\ Sir George Fisher Centre for Tropical Marine Studies, James Cook University of North Queensland, Townsville 4811 , \\ Queensland, Australia
}

\begin{abstract}
The role of bacteria in mortality of the planktonic larval stage of cultured giant clams Tridacna gigas was examined. Addition of the antibiotic chloramphenicol at $5 \mathrm{ppm}$ reduced larval mortality and confirmed the involvement of bacteria in disease prior to settlement. Symptoms of bacterial disease were usually rapid and profuse bacterial growth on and in larval clams and disintegration of most tissues within $48 \mathrm{~h}$. Results of tests in which larvae were exposed to $10^{7}$ bacteria $\mathrm{ml}^{-1}$ suggested that bacteria belonging to the genera Vibrio and Aeromonas are often pathogenic to larval clams and that those in other genera are less frequently pathogenic. Bacterial isolates with characteristics most similar to $V$. metschnikovii, $V$. alginolyticus, $V$. harveyi, $V$. splendidis I, $V$. campbelli, $V$. orientalis and Photobacterium (Vibrio) damsela caused $100 \%$ mortality. Mortality varied with different isolates of $V$. metschnikovii, $V$. alginolyticus, $V$. harveyi and $P$. damsela, suggesting isolatespecific pathogenicity. The results are discussed in terms of current knowledge of bacterial diseases of cultured marine invertebrates.
\end{abstract}

\section{INTRODUCTION}

In recent years, successful culture of the giant clam Tridacna gigas has been achieved in Australia and elsewhere (Copland \& Lucas 1988). This has provided the potential for restocking reefs, denuded of this and related species throughout the Pacific region, and for the commercial production of clams as a food source. However, a characteristic of the culture process is high mortality during the larval phase and in animals up to 6 mo of age, at which time survival is often only $0.5 \%$ or less (R. Braley, James Cook University, pers. comm.).

High mortality is typical in hatchery phases of most cultured marine invertebrates. In bivalves, most reports of bacterial disease have come from studies of commercial species from temperate regions. The species include the American oyster Crassostrea virginica (Tubiash et al. 1965, 1970, Brown 1973, 1974, 1983, Brown \& Losee 1978, Elston \& Leibovitz 1980), the hard clam Mercenaria mercenaria (Guillard 1959, Brown 1974, Brown \& Tettelbach 1988), the European flat oyster Ostrea edulis (Tubiash et al. 1965, 1970, Helm \& Smith 1971, DiSalvo et al. 1978) and the Pacific oyster Crassostrea gigas (Jeffries 1982, Garland et al. 1983). In many cases, bacteria belonging to the genus Vibrio have been found to be the principle disease agents, but aeromonads and pseudomonads have also been implicated (Sindermann 1988).

No similar studies of tropical bivalves have been undertaken. It has been assumed that bacteria are a cause of mortality in larvae of Tridacna gigas, as antibiotic applications during the larval phase improve survival rates (R. Braley pers. comm.). However, it has not been known whether bacteria initiate disease or are of secondary etiology, and if they are primary agents, whether particular bacteria are involved. With this paucity of information in mind, the present study aimed to assess the role of bacteria in mortality of larvae of this tropical bivalve. To this end, we isolated and identified bacteria associated particularly with moribund larvae and sought evidence for the role of bacteria in initiating disease in cultured larvae. Information of this nature will be needed if effective measures are to be developed to control losses in mariculture due to bacterial diseases. 


\section{MATERIALS AND METHODS}

Larval rearing. All experiments with Tridacna gigas larvae were carried out at the James Cook University Research Station at Orpheus Island (O.I.R.S.; $18^{\circ} 36^{\prime}$ S, $146^{\circ} 29^{\prime}$ E). Larval rearing procedures at the experimental rearing facility at the O.I.R.S. (which provided larvae for this study) have been described in detail by Braley et al. (1988). In summary, sperm and eggs collected from adults spawned in outdoor holding tanks were transferred to the hatchery, where fertilization occurred. Larvae were reared in the hatchery from fertilization to the veliger stage (approximately $48 \mathrm{~h}$ ), at which time they had developed a shell and were transferred to outdoor settling tanks. Settlement occurred approximately 8 to $10 \mathrm{~d}$ after fertilization. As part of normal hatchery procedures, chloramphenicol $(5 \mathrm{ppm})$ was added after fertilization. Antibiotic treatment ceased after transfer to outdoor tanks.

Antibiotic experiment. An experiment was undertaken to quantify the effect of antibiotic treatment on larval survival. The use of chloramphenicol in this aspect of the study was for experimental purposes only, emulating the use of that chemical in the rearing facility. Chloramphenicol is not recommended for general use due to its potential adverse effects on human health (Farkas et al. 1982). Following a spawning of Tridacna gigas on 15 February 1989, ten $50 \mathrm{ml}$ aliquots of rearing water containing approximately 100 fertilised eggs $\mathrm{ml}^{-1}$ were transferred to $150 \mathrm{ml}$ glass beakers. Chloramphenicol (final concentration 5 ppm; Sigma Chemical Co.) was added to 5 beakers, the other 5 received no additions. All beakers were covered with plastic petri dish lids and incubated at ambient hatchery conditions $\left(25\right.$ to $\left.28^{\circ} \mathrm{C}\right)$. After $64 \mathrm{~h}$, veliger larvae were counted and survival assessed from direct microscopic counts of 3 replicate samples of $1 \mathrm{ml}$ taken from each beaker (following mixing of the beaker contents to ensure suspension and even distribution of larvae in the water column). Larvae were considered to be dead or moribund when no movement or cellular activity was evident by microscopic examination. Empty shells were counted as dead larvae. The data, calculated as percent survival, were transformed (arcsine; Zar 1984) and analysed statistically ( 1 -way nested ANOVA).

Isolation of bacteria from larval rearing water and larvae. Bacteria from larval rearing water and moribund and healthy larvae were isolated on several occasions during the 1988-89 clam rearing season. Larvae (5 to 10 on each occasion) were collected during the pre-settlement phase of growth ( 4 to $10 \mathrm{~d}$ old) from the water column as actively swimming veligers (healthy) or from the bottom of larval rearing tanks (moribund). Moribund larvae selected for bacterial iso- lation were those with all or most tissues retained intact within the shell, but lacking any internal movement during microscopic observation. Some had bacterial streams emanating from within the shell, while others were engulfed in a film of material later observed to contain bacterial cells. After washing in several changes of sterile $\left(121^{\circ} \mathrm{C}, 110 \mathrm{kPa}, 15 \mathrm{~min}\right)$ artificial seawater (ASW), the larvae were macerated in $1 \mathrm{ml} \mathrm{ASW}$ in a sterile glass-glass hand-held homogeniser. Aliquots of $100 \mu \mathrm{l}$ of macerate were transferred to the surfaces of marine agar ( $M A_{i}$ Difco) or TCBS agar (DifCo) plates and spread evenly over the agar surfaces with a sterile glass rod. Ten-fold ASW dilutions of macerates and of larval-free rearing water from the same larval tanks were also prepared and plated as described above. Dilution ensured that plates having well-separated colonies would be obtained. The MA used during this initial isolation step was adjusted to $4 \%$ agar (Difco Bacto) to inhibit spreading bacterial growth. The ASW used was a modification of that described by Macleod (1968), and consisted of $17.55 \mathrm{~g} \mathrm{NaCl}_{1} 0.75 \mathrm{~g} \mathrm{KCl} 5.10 \mathrm{~g} \mathrm{MgSO}_{4} \cdot 6 \mathrm{H}_{2} \mathrm{O}$ and $0.145 \mathrm{~g} \mathrm{CaCl}_{2}$ per litre of distilled water ( $\left.\mathrm{pH} 7.5\right)$. The plates were incubated at ambient hatchery conditions. After $7 \mathrm{~d}$, colonies of bacteria representing the morphologies present were selected and subcultured to purity on MA using standard microbiological techniques. The bacteria were subsequently maintained at $16^{\circ} \mathrm{C}$ on this medium, with 6 -weekly subcultures.

Bacterial identification. Bacteria were identified according to phenotypic characteristics described in Bergey's Manual of Systematic Bacteriology (Kreig \& Holt 1984), Cropp \& Garland (1988), Reichelt \& Baumann (1973) and Baumann et al. (1972). Most isolates were assigned to the genera groups Aeromonas/ Plesiomonas $(\mathrm{A} / \mathrm{P})$ or Pseudomonas/Alteromonas/ Alcaligenes (P/A/A), to the genera Vibrio, Photobacterium or Moraxella, or recorded as 'not identified'. Vibrio and Photobacterium isolates were further identified using tests described by Smith et al. (1991). Vibrio isolates were tentatively assigned to species if they had $80 \%$ or greater phenotypic similarity to the described species. Isolates outside this range were recorded as Vibrio sp.

Pathogenicity testing. A total of 98 bacterial isolates from both moribund (94) and healthy (4) larvae were tested for pathogenicity to healthy veligers. Each isolate, obtained following primary isolation on MA or TCBS, was grown as a lawn plate overnight at $28^{\circ} \mathrm{C}$ on LM medium (Reichelt \& Baumann 1973), resuspended in filtered natural seawater (FSW; $0.22 \mu \mathrm{m}$, Millipore HA), and the cell density measured spectrophotometrically (Muir 1991) and adjusted to $10^{8}$ bacteria $\mathrm{ml}^{-1}$. Veligers ( $2 \mathrm{~d}$ old $)$ were rinsed several times in FSW, then transferred to $9 \mathrm{~cm}$ sterile plastic petri dishes (10 or 15 per 
dish) containing $20 \mathrm{ml}$ of FSW. Bacterial suspension was added to each dish ( 1 isolate per dish; $\mathrm{n}=1$ ) such that the final concentration was $10^{7}$ bacteria $\mathrm{ml}^{-1}$. After incubation at $28^{\circ} \mathrm{C}$ for $48 \mathrm{~h}$, veliger survival was counted and microscopic observations made. Veligers from selected treatments were preserved in $4 \%$ saline formalin for later histopathological examination. Control larvae (10 or 15 per dish; $\mathrm{n}=3$ ) were incubated in $20 \mathrm{ml} F \mathrm{FW}$ in the absence of added bacteria.

Two additional bacteria from the Australian Collection of Marine Microorganisms (ACMM; James Cook University) were included as treatments in the pathogenicity test. ACMM \#621 [Photobacterium (Vibrio) damsela; Smith et al. 1991] is a known pathogen of some marine organisms. ACMM \#16 (Pseudomonas nautica) has not been reported as a pathogen.

\section{RESULTS}

\section{Effect of antibiotic treatment on larval survival}

After incubation for $64 \mathrm{~h}$ in the presence of 5 ppm chloramphenicol, $84.75 \%$ of the veligers were alive, and the majority were actively swimming in the water column. In contrast, significantly fewer larvae were alive $(34.19 \%, p<0.0001$, Table 1$)$ following incubation in the absence of added antibiotic.

\section{Bacteria associated with rearing water, and healthy and moribund larvae}

A total of 168 bacterial isolates from larval rearing water (52), healthy (34) and moribund (82) larvae were obtained from MA primary isolation plates (Table 2). Approximately $60 \%$ of isolates from rearing water belonged to the genus group P/A/A, and $33 \%$ were Vibrio. From healthy larvae, $65 \%$ were Vibrio and P/A/A constituted approximately $32 \%$ of the bacteria obtained. Similar proportions of Vibrio and P/A/A 145 and $40 \%$ respectively) were obtained from moribund
Table 1 Tridacna gigas. Analysis of variance for the experiment in which larvae were reared in the presence or absence of $5 \mathrm{ppm}$ chloramphenicol. SS: sum of squares; df: degrees of freedom; MS: mean squares

\begin{tabular}{|lrrccc|}
\hline & SS & df & MS & $F$ & p \\
\hline Treatment & 1 & 6174.5 & 6174.5 & 114.09 & 0.0001 \\
Error & 28 & 1515.3 & 54.12 & & \\
\hline
\end{tabular}

larvae. Representatives of the genus group P/A were only found from moribund larvae (ca 10\%).

\section{Pathogenicity of bacteria to larvae and symptoms of infection}

A total of 98 bacterial isolates from moribund (94) and healthy (4) larvae were tested for pathogenicity to healthy veligers (Table 3 ). After $48 \mathrm{~h}$, most larvae in controls (Fig. 1a) were swimming actively, and mortality was usually $0 \%$ and never greater than $10 \%$. Mortality varied in bacterial treatments. For 22 bacteria, mortality similar to controls (in the range 0 to $10 \%$ ), occurred. Most of the bacteria in this category $(50 \%)$ belonged to the P/A/A group, in contrast to Vibrio and A/P which were uncommon. In comparison, of the 34 bacterial isolates associated with 91 to $100 \%$ mortality, P/A/A constituted only about $10 \%$ but Vibrio and A/P were frequently involved (50 and $32 \%$, respectively). Approximately equal proportions of Vibrio and P/A/A isolates caused mortality over the range 11 to $90 \%$. Larval mortality in the presence of bacteria was usually characterised by inactivity and a dense amorphous mass (Fig. 1b), containing bacterial cells, enveloping the shell and tissues. Histopathological examination revealed the presence of bacteria in moribund larvae and in association with the disrupted tissues. In a few treatments, bacterial overgrowth of moribund larvae was not observed (Fig. 1c), but larval tissues were in various stages of disintegration and bacterial cells were present within the shell. In some, Spirillum-like bacteria were also present.

Table 2. Identification of bacteria isolated on marine agar from larval rearing water and larvae. Data are the number of isolates in each category

\begin{tabular}{|c|c|c|c|c|c|}
\hline \multirow{2}{*}{$\begin{array}{l}\text { Source of } \\
\text { isolates }\end{array}$} & \multirow{2}{*}{$\begin{array}{l}\text { Number of } \\
\text { isolates }\end{array}$} & \multicolumn{4}{|c|}{ Bacterial genera } \\
\hline & & $\begin{array}{c}\text { Pseudomonas } \\
\text { Alteromonas } \\
\text { Alcaligenes }\end{array}$ & $\begin{array}{l}\text { Aeromonas } \\
\text { Plesiomonas }\end{array}$ & Vibrio & $\begin{array}{l}\text { Other or not } \\
\text { identified }\end{array}$ \\
\hline Rearing water & 52 & 30 & 0 & 17 & 5 \\
\hline Healthy larvae & 34 & 11 & 0 & 22 & 1 \\
\hline Moribund larvae & 82 & 37 & 8 & 33 & 4 \\
\hline Total & 168 & 78 & 8 & 72 & 10 \\
\hline
\end{tabular}


Table 3. Tridacna gigas. Larval clam mortality caused by genera of bacteria isolated on MA and TCBS from moribund and healthy larvae. Mortality among 10 or 15 larvae incubated for $48 \mathrm{~h}$ with $10^{7}$ bacteria $\mathrm{ml}^{-1}$. Data are the number of isolates in each category. Numbers in round () brackets indicate isolates from healthy larvae. Numbers in \{\} brackets are Aeromonas or Plesiomonas. Numbers in square [] brackets are Plesiomonas. Uninoculated controls ( $\mathrm{n}=3$ ) had no more than $10 \%$ mortality at $48 \mathrm{~h}$

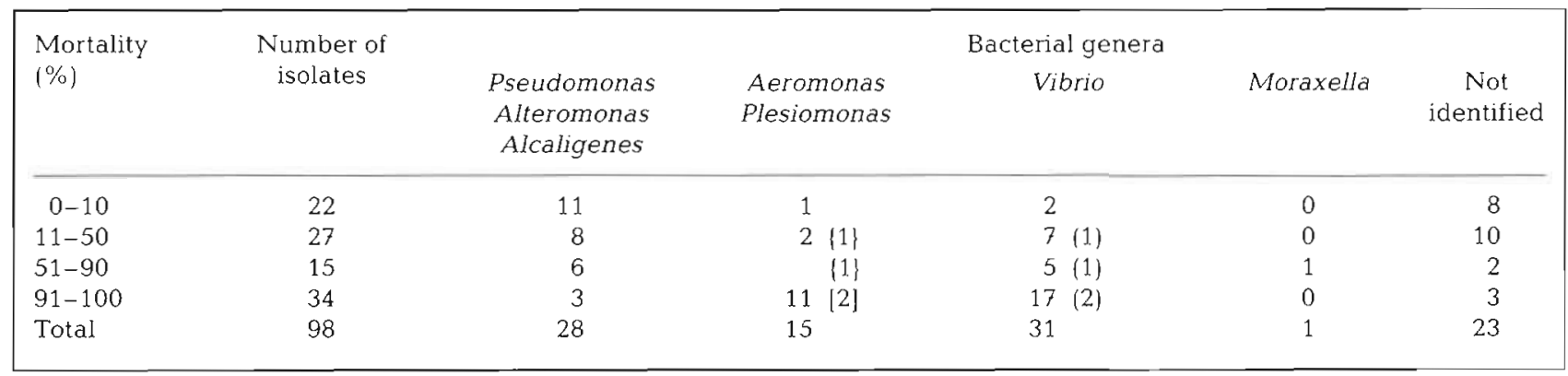

\section{Identification of Vibrio isolates in pathogenicity tests}

Of the bacteria isolated from larvae and tested for pathogenicity, 31 belonged to the genus Vibrio (Table 4). Twelve were not identified beyond genus level (Vibrio sp.), 2 had less than $80 \%$ of phenotypic characteristics in common with any described species (unidentified Vibrio sp.) and 17 were more than $80 \%$ similar to described species. Two isolates caused no mortality, 8 caused mortality in the range 10 to $50 \%, 5$ caused mortality in the range 51 to $93 \%$ and 16 caused $100 \%$ mortality. In the latter category were isolates most similar to $V$. splendidus 1 (2), $V$. orientalis (1), V. campbelli (1), V.metschnikovii (2), V.alginolyticus (4), $V$. harveyi (3) and Photobacterium (Vibrio) damsela (1). Other isolates most similar to the latter 4 species were associated with less than $100 \%$ mortality. Of note in this regard was $0 \%$ mortality with the non-clam isolate of $P$. damsela (ACMM \#621). Pseudomonas nautica caused $40 \%$ mortality

\section{DISCUSSION}

We have presented results which demonstrate that bacteria are a cause of mortality of larvae of the giant clam Tridacna gigas, described symptoms of bacterial infection and identified pathogenic bacteria. Our results show that a range of bacteria from the clam larval culture environment are able to initiate disease and cause mortality in healthy larvae under experimental conditions, but others cause no detrimental effects. The results suggest that members of the Vibrionaceae in particular are able to initiate disease, but isolates of particular species differ in pathogenicity.

The effectiveness of chloramphenicol in increasing survival of larvae demonstrated that bacteria contribute significantly to larval mortality. However, it was important to seek evidence for the involvement of particular bacteria in causing disease. The genus group A/A/P (Alcaligenes, Alteromonas or Pseudomonas) and the genus Vibrio were normal constituents of the culture environment and of healthy animals in culture, and were also associated with moribund larvae. In contrast, the genera Aeromonas and Plesiomonas were only found from moribund larvae. Pure isolates, predominantly from moribund larvae, were tested for pathogenicity. Most Vibrio and Aeromonas isolates caused more than $90 \%$ mortality, and few were associated with less than $10 \%$ mortality. Isolates of Plesiomonas, though rare, were similarly pathogenic. In contrast, isolates of the genus group $\mathrm{A} / \mathrm{A} / \mathrm{P}$ usually caused less than $10 \%$ mortality. The evidence therefore suggests that, as with temperate bivalves (Sindermann 1988), the principal pathogenic bacteria of giant clam larvae are members of the Vibrionaceae, but members of other genera may also cause disease. Isolates most similar to $V$. alginolyticus, $V$. harveyi, $V$. splendidis 1, V. metschnikovii, $V$. campbelli, $V$. orientalis and Photobacterium (Vibrio) damsela were associated with $100 \%$ mortality. Of these, $V$. alginolyticus (Sindermann 1988), V. harveyi, V. splendidis 1 (Pitogo 1.988) and $P$. damsela (Muir 1991) have previously been reported to be pathogenic to invertebrate larvae, although of these only $V$. alginolyticus has been reported from bivalve larvae (Sindermann 1988).

Results for Photobacterium (Vibrio) damsela in particular suggested intraspecific differences in pathogenicity to clam larvae and differences in pathogenicity amongst different invertebrates. The isolate from clam larvae caused $100 \%$ mortality, but a nonclam isolate of this species, included in these experiments because of its pathogenicity to prawn larvae (Muir 1991) caused no mortality. Similar intraspecific differences were obtained with clam isolates most similar to $V$, harveyi and $V$. alginolyticus.

Two of the 4 bacterial isolates from apparently healthy larvae caused $100 \%$ mortality. This suggests 

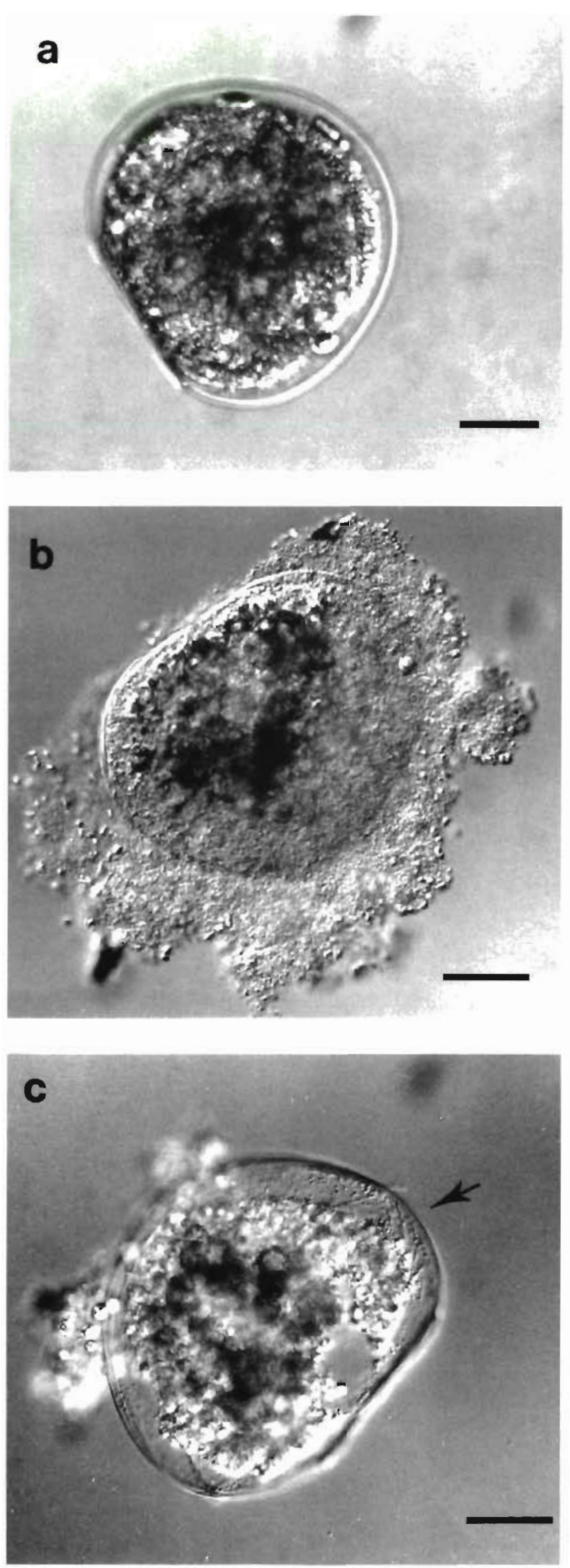

Table 4. Identification of Vibrio spp. isolates from Tridacna gigas larvae and results of testing their pathogenicity to healthy larvae. Vibrio spp. isolates having $>80 \%$ similarity to described species are assigned, those having $<80 \%$ similarity are described as 'unidentified Vibrio sp.' and those identified only to genus level are described as 'Vibrio sp.' 'One isolate in this category came from healthy larvae. ACMM = Australian Collection of Marine Microorganisms

\begin{tabular}{|lcc|}
\hline Bacterial identification & $\begin{array}{c}\text { Number of } \\
\text { isolates }\end{array}$ & $\begin{array}{c}\% \text { Mortality } \\
\text { among larvae }\end{array}$ \\
\hline Vibrio sp. & 1 & 0 \\
Photobacterium damsela & 1 & 0 \\
$\quad$ (ACMM \#621) & 1 & 0 \\
Unidentified Vibrio sp. & 1 & 10 \\
Unidentified Vibrio sp. & 5 & $11-50^{.}$ \\
Vibrio spp. & 1 & 40 \\
V. harveyi & 1 & 40 \\
Pseudomonas nautica & & \\
$\quad$ (ACMM \#16) & 1 & 40 \\
V. alginolyticus & 4 & $91-90^{\circ}$ \\
Vibrio spp. & 1 & 100 \\
V. metschnikovii & 2 & $100^{\circ}$ \\
Vibrio spp. & 2 & 100 \\
V. alginolyticus & 4 & 100 \\
V. campbelli & 1 & 100 \\
P. damsela & 1 & 100 \\
V. harveyi & 3 & 100 \\
V. orientalis & 1 & 100 \\
V. splendidis 1 & 2 & \\
& & \\
\hline
\end{tabular}

that species forming part of the normal larval microflora are able to cause disease under certain conditions. One of these conditions may be bacterial concentration. The concentration used $\left(10^{7} \mathrm{ml}^{-1}\right)$ was similar to that in other studies of pathogenicity of bacteria to bivalve larvae (summarised by Jeffries 1982), but is probably in excess of that to which larvae in the water column would be exposed. Future studies to determine whether pathogenicity is dose-related would be warranted. However, consideration only of bacterial concentration in suspension may be misleading in studies of bacterial diseases of larvae of invertebrates which become sessile. Under normal hatchery operating conditions, mortality of larval giant clams is greatest up to and including settlement (R. Braley pers. comm.). At settlement in particular but also during the planktonic phase, when temporary settlement to the

Fig. 1. Tridacna gigas. Symptoms of bacterial infection in larvae after $48 \mathrm{~h}$ of incubation with $10^{7}$ bacteria $\mathrm{ml}^{-1}$. (a) Control larva incubated in the absence of added bacteria. (b) Moribund larva engulfed in a mucilaginous film containing bacterial cells. (c) Moribund larva with disintegrating tissues and with bacteria (including Spirillum-like types) only apparent peripherally (arrow) within the shell. Nomarsky interference contrast. Scale bar $=100 \mu \mathrm{m}$ 
bottom of the tank may occur, larvae may be exposed to localised high concentrations of pathogenic bacteria associated with the tank surfaces and with dead and moribund larvae on those surfaces. This may account for much of the larval losses during rearing. Elston et al. (1982) reported the association of surface-associated Vibrio spp. with disease of juvenile Crassostrea virginica, Mercenaria mercenaria and Ostrea edulis.

Symptoms of disease due to individual bacterial isolates varied, but were most commonly the appearance of a bacterial film engulfing the larvae and almost complete tissue disintegration within $48 \mathrm{~h}$. Moribund larvae in rearing vessels had similar symptoms, but there were usually numerous protozoans also present, apparently feeding on the clam tissues and bacteria. The progress of bacterial disease in larvae of the tropical bivalve Tridacna gigas therefore parallels that in other larval molluscs (Tubiash et al. 1965, DiSalvo et al. 1978, Jeffries 1982). Spirillum-like bacteria were also apparent within the shell of some moribund veligers. Jeffries (1982) reported similar bacteria associated with mortality of Ostrea edulis and Crassostrea gigas larvae (pathogenic Vibrio spp. strains were subsequently isolated from the latter). These bacteria are probably secondary invaders, normally associated with larvae.

It seems likely that prophylactic use of antibiotics to control bacterial populations in some mariculture hatcheries has led to resistance among certain bacteria pathogenic to cultured invertebrates (e.g. Baticados et al. 1990), creating major difficulties in control of diseases they cause. Alternative methods to the use of antibiotics must be sought. It is therefore important that the contribution of bacteria to disease in each culture situation be determined and that pathogenic bacteria be identified. The finding in this study that some bacteria are pathogenic but that many, even at high concentration, cause little or no mortality to Tridacna gigas larvae may be significant for the development of new disease-control stategies. Similar results were found by Garland et al. (1983) in investigation of Crassostrea gigas culture. It raises the possibility of future application of non-pathogenic bacteria as competitors of disease-causing species in hatchery situations. The identification of pathogenic bacteria also provides the opportunity for development of specific, non-chemical control methods.

Acknowledgements. The authors thank Dr Richard Braley and staff of the 'Giant Clam Project' and James Cook University Orpheus Island Research Station, for support and assistance in the field, and Dr Rob van Woesik for assistance with statistics. Dr Jane Fromont and Heidi Streiner offered useful comments during preparation of the manuscript. The research was supported by a grant from the Australian Marine Science and Technologies Grants Scheme.

\section{LITERATURE CITED}

Baticados, M. C. L., Lavilla-Pitogo, C. R., Cruz-Lacierda, E. R., de la Peña, L. D., Suñaz, N. A. (1990). Studies on the chemical control of luminous bacteria Vibrio harveyi and $V$. splendidus isolated from diseased Penaeus monodon larvae and rearing water. Dis. aquat. Org. 9: $133-139$

Baumann, L., Baumann, P., Mandel, M., Allen, R. D. (1972). Taxonomy of aerobic marine eubacteria. J. Bacteriol. 110: $402-429$

Braley, R. D., Nash, W. J., Lucas, J. S., Crawford, C. M. (1988). Comparison of different hatchery and nursery culture methods for the giant clam Tridacna gigas. In: Copland, J. W., Lucas, J. S. (eds.) Giant clams in Asia and the Pacific. Australian Centre for International Agricultural Research, Monograph No. 9, p. 110-114

Brown, C. (1973). The effects of some bacteria on embryos and larvae of the American oyster, Crassostrea virginica. J. Invertebr. Pathol. 21: 215-223

Brown, C. (1974). A pigment producing pseudomonad which discolours culture containers of embryos of a bivalve mollusc. Chesapeake Sci. 15: 17-21

Brown, C. (1983). Bacterial disease in bivalve larval cultures and their control. In: Berg, C. J. Jr (ed.) Culture of marine invertebrates: selected readings. Hutchinson Ross Publ. Co., Pennsylvannia, p. 230-242

Brown, C., Losee, E. (1978). Observations of natural and induced epizootics of vibriosis in Crassostrea virginica Iarvae. J. Invertebr. Pathol. 31: 41-47

Brown, C., Tettelbach, L. (1988). Characterisation of a nonmotile Vibrio species pathogenic to the larvae of Mercenaria mercenaria and Crassostrea virginica. Aquaculture 74: 195-204

Copland, J. W., Lucas, J. S. (1988). Giant clams in Asia and the Pacific. Australian Centre for International Agricultural Research, Monograph No. 9, Canberra

Cropp, C. M., Garland, C. D. (1988). A scheme for the identification of marine bãcteria. Aust. Microbiologist 9: $27-34$

DiSalvo, L. H., Bloeka, J., Zebal, R. T (1978). Vibrio anguillarum and larval mortality in a California shellfish hatchery. Appl. environ. Microbiol. 35: 219-221

Elston, R., Elliot, E., Colwell, R. R. (1982). Conchiolin infection and surface coating Vibrio: shell fragility, growth depression and mortalities in cultured oysters and clams, Crassostrea virginica, Ostrea edulis and Mercenaria mercenaria. J. Fish Dis. 5: 265-284

Elston, R., Leibovitz, L. (1980). Pathogenesis of experimental vibriosis in larval American oysters, Crassostrea virginica. Can. J. Fish. Aquat. Sci. 37: 964-978

Farkas, J., Olah, J., Szecsi, E. (1982). Antibiotic sensitivity of bacteria isolated from water and fish. Aquaculture Hungarica (Szarvas) 3: 85-92

Garland, C. D., Nash, G. V., Sumner, C. E., McMeekin, T A. (1983). Bacterial pathogens of oyster larvae (Crassostrea gigas) in a Tasmanian hatchery. Aust. J. mar. Freshwat. Res. 34: 483-487

Guillard, R. L. (1959). Further evidence for the destruction of bivalve larvae by bacteria. Biol. Bull. 117: 258-266

Helm, M. M. Smith, F. M. (1971). Observations on a bacterial disease in laboratory cultured larvae of the European flat oyster Ostrea edulis L. Comm. Meet. int. Counc. Explor. Sea C.M.-ICES 1971/K: 10

Jeffries, V. E. (1982). Three Vibrio strains pathogenic to larvae of Crassostrea gigas and Ostrea edulis. Aquaculture 29 $201-226$ 
Kreig, N. R., Holt, J. G. (eds.) (1984). Bergey's Manual Of Systematic Bacteriology, Vol. 1 Williams \& Wilkins Co., Baltimore

Macleod, R. A. (1968). On the role of inorganic ions in the physiology of marine bacteria. Adv. Microbiol. Sea 1. 95-126

Muir, P. R. (1991). Factors affecting the survival of penaeid prawns in culture with particular reference to the larval stages. Ph.D. thesis, James Cook University of North Queensland, Townsville

Pitogo, C. R. (1988). Isolation and identification of luminous bacteria causing mortalities in Penaeus monodon hatcheries in Panay. SEAFDEC Asian Aquaculture 10: 9

Reichelt, J. L., Baumann, P. (1973). Taxonomy of the marine, luminous bacteria. Arch. Mikrobiol. 94: 283-330

Sindermann, C. J. (1988). Vibriosis of larval oysters. In: Sindermann, C. J., Lightner, D. V. (eds.) Disease diagnosis

Responsible Subject Editor: A. K. Sparks, Seattle, Washington, USA and control in North American marine aquaculture. Developments in aquaculture and fisheries science, No. 17. Elsevier, Amsterdam

Smith, S. K., Sutton, D. C., Fuerst, J. A., Reichelt, J. L. (1991). Evaluation of the genus Listonella and reassignment of Listonella damsela (Love et al.) MacDonell and Colwell to the genus Photobacterium as Photobacterium damsela comb. nov. with an emended description. Int. J. system. Bacteriol. 41: 529-534

Tubiash, S. H., Chanley, P. E., Leifson, E. (1965). Bacillary necrosis, a disease of larval and juvenile bivalve mollusks. I. Etiology and epizootiology. J. Bacteriol. 90: 1036-1044

Tubiash, S. H., Colwell, R. R., Sakazaki, R. (1970). Marine vibrios associated with bacillary necrosis, a disease of larval and juvenile bivalve mollusks. J. Bacteriol. 103: 272-273

Zar, J. H. (1984). Biostatistical analysis. Prentice-Hall, Inc., Englewood Cliffs

Manuscript first received: January 4, 1993 Revised version accepted: March 18, 1993 